\title{
Insecticide Use and Farmers Perception on Cabbage Cultivation in Nine Districts of Karnataka, India
}

\author{
Ravi Biradar ${ }^{1}$, M Bheemanna ${ }^{1}$, A. Hosamani ${ }^{1}$, Harischandra Naik ${ }^{1}$, \\ Nagaraj Naik ${ }^{2}$ and Kavita Kandpal ${ }^{3}$ \\ ${ }^{1}$ Department of Agricultural Entomology, University of Agricultural Sciences, \\ Raichur-584 102, India \\ ${ }^{2}$ Department of Agriculture Microbiology, University of Agricultural Sciences, \\ Raichur-584 102, India \\ ${ }^{3}$ Department of Horticulture, University of Agricultural Sciences, \\ Bengaluru, 560065, India \\ *Corresponding author
}

\section{A B S T R A C T}

Keywords

Cabbage, crop

label,

organophopshates,

diamides and

chlorantraniliprole

Article Info

Accepted:

15 December 2019

Available Online:

20 January 2020
Resultantly, in cabbage growing ecosystem of Karnataka as many as 33 insecticides are being used, in which $58 \%$ insecticide are not having crop label. Majority of Bidar, Belagavi, Raichur, Chikmagalur and Hassan district farmers were relied on organophosphate insecticides to manage insect pest in cabbage crop while Bengaluru, Mysuru and Chamrajnagar districts farmer are mainly dependent on diamides and combination products for the management of cabbage pests. Profenofos, fipronil, emamectin benzoate and chlorantraniliprole were predominately spraying chemicals throughout the cabbage growing areas of Karnataka. Cabbage farmers of all nine spatially isolated districts used the insecticides at higher than the recommended dosage. Further, total number of sprays was Maximum in Haveri (14-16 sprays) while minimum in Bidar (6-8 sprays) during a cropping season. The research has exposed some of overuse, misuse and abuse of pesticides among farmers.

\section{Introduction}

Cabbage (Brassica oleracea var. capitata L.) is one of the widely grown vegetable crops in
India. Its cultivation is spread across temperate to tropical climatic conditions and constitutes the most important component in the diets of various cultures (Shelton 2004). In 
India, cabbage is grown in an area of $4.06 \mathrm{~m}$ ha with a production of $8.97 \mathrm{MT}$ with an average productivity of $25 \mathrm{tha}^{-1}$ (NHB 2018). Productivity of cabbage in India is much lower attributing to many causes and among them insect pests are the major constraints. It has been anticipated that insect pests alone causes $40 \%$ to $100 \%$ yield loss annually (Hasan and Ansari, 2011).

Earlier in India, 37 insects' pests were reported in cabbage viz., Diamond back moth (Plutella xylostella), Mustard aphid (Lipaphis erysimi), Cabbage semilooper (Trichoplusia ni), Tobacco caterpillar (Spodoptera litura),cutwom (Agrotis ipsylon) etc. Among them, $P$. xylostella is the most destructive insect pest of cabbage and even more difficult pest to control. The core of control measure under intensified farming is the frequent use of insecticides.

Moreover, redundant use of broad-spectrum insecticides for its control not only increased the cost of production, but also led to environmental pollution through toxic residue (Guo et al., 1999). Organochlorines, organophosphates, pyrethroids and fungicides are major groups of pesticides used and on an average, 8-9 applications of pesticides are being applied per crop per season (Handigol and Kulkarni, 2010). Farmers often increase the dose of insecticides and take up spray to 25 times within a cropping season (Khan et al., 1991).

Farmers with formal education were more likely to stick on to the recommended application rates of pesticides (Amoabeng et al., 2017). The excessive dependency on chemical control led to development of resistance to all major group of insecticides used extensively against it. As a result, every new insecticide is expected to have potential effectiveness for just two or three years.

Though number of studies were conducted on the knowledge and pesticide use, the changing scenario warrants more studies. In view of this, a survey was undertaken to document insecticide usage pattern and to determine the relative predominance of individual insecticide molecule in major cabbage growing districts of Karnataka during 20172019.

\section{Materials and Methods}

Insecticide usage pattern adopted by cabbage growers to manage cabbage insect pests was collected through roving survey in fixed villages using a questionnaire during 20172019 from the major cabbage growing areas of Karnataka. Survey area included the major cabbage growing districts of Karnataka viz., Raichur, Bidar, Belagavi, Haveri, Chikmagalur, Hassan, Chamrajnagar, Mysuru and Bengaluru. In each district two major cabbage growing taluks were selected and from those taluks, 5-8 villages were selected.

Totally 20 farmers per district constituted the sample size to gather information on insecticide usage pattern. In the cropping season, each district was visited twice during 2017-18 and 2018-19 and interaction was done with 20 farmers with a schedule on various aspects of insect pest control including insecticide usage pattern. Information on insecticides being used, dosage per application, number of insecticide applications per crop, number of times a particular insecticide was used, agronomic practices they followed and the relative efficacy as perceived by farmers was collected.

Later, information on number of insecticides, dosage and extent of use of each insecticide and relative usage in terms of number of sprays was computed for each location and for overall cabbage ecosystem of major cabbage growing districts of Karnataka. 


\section{Results and Discussion}

In cabbage growing ecosystem of Karnataka as many as 33 insecticides are being used, in which 7 are commercially available combination products. It is evident from survey that over all 26 insecticides and seven combination products belongs to various chemical group with different mode of action have been used in Karnataka to cabbage pests. In which Organophosphates $(26.16 \%)$ and combination products $(23.84 \%)$ are taken major share (Table 1).

Maximum of 17 different insecticides were used by the farmers of Haveri and Bengaluru district. While Chamrajnagar and Mysuru farmers used 14 different insecticides in cabbage ecosystem, whereas the Raichur and Belagavi farmers used 13 different insecticides, Hassan farmers used 12 insecticides and relatively less compounds were used by Bidar and Chikmagalur farmers (11 insecticides).

Results are in accordance with Siddartha (2013) whose survey data revealed that farmers were using 16 insecticides, seven fungicides and three plant growth regulators on cabbage crop. The insecticide usage pattern varied greatly between and within the locations indicating no definite insecticide usage pattern among the major cabbage growing districts of Karnataka.

This might be due to the fact that, majority of the farmers of cabbage growing areas of Karnataka were greatly influenced by the dealer's recommendations and repeatedly used the same insecticides as recommended by the pesticide dealers. The main reason for this dependence appeared to be that most farmers were economically poor and depended on the dealers for credit, these results are in line with the reports of Lingappa et al.(1993).

The total number of insecticide sprays ranged between fourteen to sixteen with spray interval of 3-4 days in Bengaluru and Haveri districts while, in Chamrajnagar it ranged between twelve to fourteen sprays with 3-5 days spray interval. Whereas, in Belagavi, Raichur and Mysuru number of sprays ranged between 1012 with 4-6 days spray interval.

Number of sprays ranged from 8-10 with a week interval in Hassan and Chikmagalur. Whereas Bidar farmers used only seven sprays with 10-12 days interval (Table 2).

Presented results were in accordance with the report of Jeyanti and Kombairaju (2005) they examined pest management in vegetables crops viz., cauliflower, chilli, cabbage brinjal and bhendi. On an average cauliflower, cabbage and brinjal were given 15 applications, chilli and bhendi were given 13 and 12 applications, respectively. Similarly our findings supported by Katinka and Srinivasan (2009).

Cabbage farmers of all nine spatially isolated districts used the insecticides at higher than the recommended dosage. Haveri and Bengaluru district farmers used comparatively little higher dosage of insecticides as compared to other seven districts cabbage growers.

Thirteen insecticide groups were used by the farmers for the management of insect pests on cabbage ecosystem of major cabbage growing districts of Karnataka. Organophosphates were the most commonly used insecticides followed by spinosyns, phenyl pyrrazole, synthetic pyrethroids and actinomycetes in Bidar, Raichur, Belagavi, Chikmagalur and Hassan districts of Karnataka. 
Table.1 Extent of usage of insecticides (\%) in cabbage ecosystem of major cabbage growing districts of Karnataka during 2017-2019

\begin{tabular}{|c|c|c|c|c|c|c|c|c|c|c|c|}
\hline Chemical Group & Insecticides & Raichur & Bidar & Belgaum & Chikmagalur & Hassan & Chamanagar & Mysore & Haveri & Bengaluru & Overall \\
\hline \multirow[t]{7}{*}{ Organophosphates } & Phenthoate $50 \%$ EC & 9.42 & -- & -- & -- & -- & 11.77 & 11.71 & -- & 8.73 & 4.14 \\
\hline & Profenofos $50 \%$ EC & 11.52 & 15.05 & 13.32 & 13.97 & 13.43 & 11.62 & 11.94 & -- & -- & 4.30 \\
\hline & Chlorpyrifos $20 \%$ EC & -- & 16.16 & 12.24 & 15.92 & 13.18 & -- & -- & -- & -- & 4.39 \\
\hline & Acephate $75 \%$ SP & 7.74 & 6.41 & 7.02 & 6.26 & 6.24 & -- & -- & -- & 4.76 & 2.28 \\
\hline & Monocrotophos $36 \%$ SL & 10.00 & -- & -- & -- & -- & -- & -- & -- & -- & 4.19 \\
\hline & Dichlorvos $76 \%$ EC & -- & 11.65 & 11.43 & 10.06 & -- & -- & -- & 8.97 & -- & 3.49 \\
\hline & Quinalphos 25\% EC & -- & 10.87 & 12.80 & 9.26 & 10.50 & -- & -- & -- & -- & 3.36 \\
\hline Total & & 38.68 & 60.13 & 56.81 & 55.46 & 43.35 & 23.39 & 23.65 & 8.97 & 13.49 & 26.16 \\
\hline \multirow[t]{3}{*}{ Neonicotinoids } & Imidacloprid $17.8 \% \mathrm{SL}$ & -- & -- & 1.47 & -- & -- & 2.43 & 3.28 & 1.82 & 1.43 & 0.80 \\
\hline & Acetamiprid 20\% SP & -- & 1.84 & 2.02 & -- & -- & -- & -- & 1.09 & -- & 0.56 \\
\hline & Thiamethoxam $25 \%$ WG & -- & 1.82 & -- & -- & -- & 2.34 & -- & 3.04 & -- & 0.89 \\
\hline Total & & -- & 3.66 & 3.49 & -- & -- & 4.77 & 3.28 & 5.96 & 1.43 & 2.25 \\
\hline \multirow[t]{2}{*}{ Carbmates } & Thiodicarb $75 \%$ WP & -- & -- & -- & -- & -- & -- & -- & 9.85 & -- & 4.38 \\
\hline & Cartap hydrochloride & -- & -- & 10.61 & 11.17 & -- & -- & -- & -- & -- & 3.38 \\
\hline Total & & -- & -- & 10.61 & 11.17 & -- & -- & -- & 9.85 & -- & 7.77 \\
\hline \multirow{3}{*}{ Spinosyns } & Spinosad $2.5 \%$ SC & 6.32 & -- & 8.81 & -- & 8.54 & -- & -- & -- & -- & 2.80 \\
\hline & Spinosad $45.0 \%$ SC & & -- & 4.41 & 5.59 & 4.88 & 3.98 & 3.75 & 2.97 & 3.90 & 1.53 \\
\hline & Spinetoram $11.7 \%$ SC & & -- & -- & 8.72 & 7.89 & 7.10 & 6.74 & 6.13 & 6.03 & 2.63 \\
\hline Total & & 6.32 & -- & 13.22 & 14.30 & 21.32 & 11.07 & 10.49 & 9.10 & 9.93 & 6.96 \\
\hline \multirow[t]{3}{*}{ Diamides } & $\begin{array}{l}\text { Chlorantraniliprole } 18.5 \% \\
\text { SC }\end{array}$ & 1.81 & 1.46 & 1.67 & 1.74 & 1.86 & 2.98 & 2.11 & 1.58 & 2.12 & 0.71 \\
\hline & $\begin{array}{l}\text { Cyantraniliprole } 10.26 \% \\
\text { OD }\end{array}$ & & -- & -- & -- & -- & -- & 7.26 & 6.20 & 7.30 & 3.00 \\
\hline & Flubendiamide $20 \%$ WG & 5.16 & -- & -- & -- & -- & 9.83 & 6.22 & 6.32 & 5.90 & 2.71 \\
\hline Total & & 6.97 & 1.46 & 1.67 & 1.74 & 1.86 & 12.81 & 15.59 & 14.11 & 15.32 & 6.43 \\
\hline \multirow[t]{2}{*}{ Benzoyl phenyl ureas } & Novaluron $10 \%$ EC & & 13.59 & -- & -- & -- & 9.20 & 8.52 & -- & 7.93 & 3.50 \\
\hline & Chlorfluazuron $5.4 \%$ EC & & -- & -- & -- & -- & -- & -- & 11.40 & 11.90 & 5.58 \\
\hline Total & & & 13.59 & -- & -- & -- & 9.20 & 8.52 & 11.40 & 19.83 & 9.08 \\
\hline Phenyl pyrazole & Fipronil 5\% SC & 8.75 & 12.33 & 12.13 & 14.53 & 11.58 & -- & -- & -- & -- & 3.84 \\
\hline Synthetic pyrethroids & Lambda-cyhalothrin 5\% EC & 4.07 & 5.82 & -- & -- & 4.94 & -- & 4.87 & -- & 5.08 & 1.85 \\
\hline Oxidiazines & Indoxacarb $14.5 \% \mathrm{SC}$ & & -- & -- & -- & -- & -- & -- & 3.89 & 4.55 & 2.03 \\
\hline Pyrroles & Chlorfenapyr 10\% SC & 10.32 & -- & -- & -- & -- & -- & -- & 9.49 & -- & 4.27 \\
\hline Pyrazoles & Tolfenpyrad $15 \%$ EC & & -- & -- & -- & -- & 11.52 & 11.80 & 9.54 & 9.20 & 4.26 \\
\hline Actinomycetes & Emamectin benzoate 5\% & 3.58 & 2.98 & 2.06 & 2.79 & 2.29 & 4.21 & 8.43 & 2.37 & 2.54 & 1.26 \\
\hline
\end{tabular}




\begin{tabular}{|c|c|c|c|c|c|c|c|c|c|c|c|}
\hline & SG & & & & & & & & & & \\
\hline \multirow[t]{7}{*}{ Combi product } & $\begin{array}{l}\text { Deltamethrin } 1 \%+ \\
\text { Trizophos } 35 \% \mathrm{EC}\end{array}$ & 9.68 & -- & -- & -- & -- & -- & -- & -- & -- & 4.06 \\
\hline & $\begin{array}{l}\text { Flubendiamide } 19.92 \%+ \\
\text { Thiacloprid } 480 \% \text { SC }\end{array}$ & -- & -- & -- & -- & -- & 5.85 & -- & -- & 4.36 & 2.13 \\
\hline & $\begin{array}{l}\text { Chlorpyrifos 50\%+ } \\
\text { Cypermethrin 5\%EC }\end{array}$ & -- & -- & -- & -- & -- & 11.23 & 7.03 & -- & 7.93 & 3.46 \\
\hline & $\begin{array}{l}\text { Thiamethoxam } \\
\text { 12.6\%+Lambda cyhalothrin } \\
9.5 \% \text { ZC }\end{array}$ & -- & -- & -- & -- & -- & 5.93 & 6.32 & -- & 6.35 & 2.50 \\
\hline & $\begin{array}{l}\text { Novaluron } 5.25 \%+ \\
\text { Indoxacarb } 4.5 \% \mathrm{SC}\end{array}$ & -- & -- & -- & -- & -- & -- & -- & 7.66 & -- & 3.41 \\
\hline & $\begin{array}{l}\text { Profenofos } 40 \%+ \\
\text { Cypermethrin } 4 \% \text { EC }\end{array}$ & 11.61 & -- & -- & -- & 14.65 & -- & -- & -- & -- & 4.87 \\
\hline & $\begin{array}{l}\text { Novaluron } 5.25 \%+ \\
\text { Emamectin Benzoate } 0.9 \% \\
\text { SC }\end{array}$ & -- & -- & -- & -- & -- & -- & -- & 7.66 & -- & 3.41 \\
\hline Total & & 21.29 & -- & -- & -- & 14.65 & 23.01 & 13.35 & 15.32 & 18.64 & 23.84 \\
\hline
\end{tabular}

Table.2 Number of insecticides and applications with spray interval against cotton insect pests in major cabbage growing districts of Karnataka

\begin{tabular}{|c|c|c|c|}
\hline Location & Number of insecticide used & Total number of sprays & Spray interval \\
\hline Bidar & 11 & $6-8$ & $10-12$ \\
\hline Belagavi & 13 & $11-13$ & $4-6$ \\
\hline Haveri & 17 & $14-16$ & $3-4$ \\
\hline Chikmagalur & 11 & $8-10$ & $6-8$ \\
\hline Hassan & 12 & $10-12$ & $5-7$ \\
\hline Mysuru & 14 & $4-6$ & $10-12$ \\
\hline Bengaluru & 14 & $14-16$ & $3-4$ \\
\hline Chamrajnagar & 14 & $12-14$ & $3-5$ \\
\hline Raichur & 13 & $9-11$ & $4-6$ \\
\hline
\end{tabular}


While, in Chamrajnagar, Mysuru, Bengaluru and Haveri diamides group of insecticides were majorly used and was followed by combination products, organophosphates, benzyl phenyl ureas and spinosyns.

Chlorantraniliprole and emamectin benzoate were the most common insecticides used in all major cabbage growing districts. But in Raichur, Bidar, Belagavi, Chikmagalur and Hassan districts fipronil and profenofos were the commonly used insecticides, while in Chamrajnagar, Mysuru, Haveri and Bengaluru flubendiamide was the most commonly used insecticide as compared to chlorantraniliprole (Table 1).

Similar kind of results are documented by Mukherjee and Singh (2005) The most commonly used insecticides were methyl parathion, endosulfan, carbofuran, phosphamidon, quinolphos, dimethoate and in some cases cartap hydrochloride. Prsented studies are in line with the Raghavendra, (2005) and Nagendra (2009) on insecticides used in major cabbage growing areas of Belagavi district.

Prolonged use of the same insecticides would definitely elevate the problem of insecticide resistance, as experienced in Andhra Pradesh, and Karnataka during late 1980s and early 1990s (Kranthi et al., 2001). Identification of insecticide usage patterns allows for the rotation of insecticides and the rational use of pesticides for the better management of pest and for insecticide resistance (Lingappa et al., 1993).

There is a greater need for educating the farmers about the pests, insecticides, rotation and rational use of insecticides and their uses to avoid indiscriminate usage and to prevent a chain of problems that affect environment and human health.

\section{Acknowledgement}

With at most pleasure and sincerity, the senior author thankfully acknowledge whole heartedly Indian council of agriculture research, Government of India for providing financial assistance by awarding ICARSenior research fellowship to pursue Ph.D. in Agricultural Entomology at the University of Agricultural Sciences, Raichur.

\section{References}

Amoabeng, B. W., Asare, K. P., Asare, O. P., Mochiah, M. B., Adama, I., Fening, K. O. and Gurr, G. M., 2017, Pesticides use and misuse in Cabbage Brassica oleracea var. capitata L. (Cruciferae) production in Ghana: the influence of farmer education and training. $J$. Agric. Eco. Res. Int., 1-9.

Guo, M., Zhu, D. and Li, L., 1999, Selection of Trichogramma species for controlling the diamondback moth Plutella xylostella (L.). Insect Science, 6(2): 187-192.

Handigol, J. A. and Kulkarni, V. A. 2010, Pesticide use in cabbage production in Belgaum district of Karnataka: an economic analysis. Green Farm., 1(3): 290-293.

Hasan, F. and Ansari, M. S., 2011, Population growth of Pieris brassicae (L.) (Lepidoptera: Pieridae) on different cole crops under laboratory conditions. $J$. Pest Sci., 84(2): 179-186.

Jeyanthi, H. and Kombairaju, S., 2005, Pesticide use in vegetable crops: frequency, intensity and determinant factors. Agric. Econ. Res. Rev., 18: 209221.

Kanwaljit, K., Bikramdeep, S. and Prabhjot, K., 2010, Use of insecticides and indigenous practices on cabbage crop by vegetable growers of Ludhiana 
district (Punjab). Int. J. Plant Pro., 3(1): $154-157$.

Katinka, W. and Srinivasan, R., 2009, Farmers management of cabbage and cauliflower pests in India and their approaches to crop protection. J. AsiaPacific Entomo., 12: 253-259.

Khan, H. K., Nagaraj, G. N. and Reddy, S. Y., 1991, Integrated pest management demonstrations in cabbage. Plant Protection Bulletin, 43: 11-12.

Kranthi, K. R., Jadhav, D. R., Wanjari, R. R., Ali, S. S. and Russell, D., 2001, Carbamate and organophosphate resistance in cotton pests in India, 1995 to 1999. Bulletin of Entomological Research, 91(1): 37-46.

Lingappa, S., Panchabhavi, K. S. and Hugar, P. S., 1993, Managament of cotton bollworms with special reference to Heliothis in Karnataka. Pestology, 17(9): 20-25.

Mukherjee, U. and Singh, H. N., 2005, Pesticide use pattern on cabbage and cauliflower against diamondback moth Plutella xylostella, Curt in Varanasi (Uttar Pradesh). J. Res., 17(1): 69-75.
Nagendra, 2009, Economic consequences of pesticide use in cabbage production in Belgaum district of Karnataka. M.Sc Thesis. Univ. Agric. Sci., Dharwad, India

NHB, 2018, Indian Horticulture Database, 2017-18. National Horticulture Board (NHB), Ministry of Agriculture, Government of India, IG Printer, New Delhi

Raghavendra, R., 2005, Study on knowledge and adoption of recommended cultivation practices of Cauliflower growers in Belgaum district of Karnataka (Doctoral dissertation, UAS, Dharwad).

Shelton, A. M. and Nault, B. A., 2004, Deadend trap cropping: a technique to improve management of the diamondback moth, Plutella xylostella (Lepidoptera: Plutellidae). Crop Protection, 23(6): 497-503.

Siddartha, D., 2013, Studies on compatibility of chemicals against diamondback moth, Plutella xylostella 1. (Lepidoptera: Plutellidae). M.Sc.(Horti) Thesis, Univ. Horti. Sci., Bagalkot.

\section{How to cite this article:}

Ravi Biradar, M Bheemanna, A. Hosamani, Harischandra Naik, Nagaraj Naik and Kavita Kandpal. 2020. Insecticide Use And Farmers Perception On Cabbage Cultivation In Nine Districts Of Karnataka. Int.J.Curr.Microbiol.App.Sci. 9(01): 1461-1467. doi: https://doi.org/10.20546/ijcmas.2020.901.162 